\title{
Current and Future Trends and Issues Facing Technology and Engineering Education in the United States
}

\author{
Johnny J. Moye, Philip A. Reed, Ray Wu-Rorrer, \& Douglas Lecorchick
}

\begin{abstract}
Determining trends and issues is important for the health of any profession. The purpose of this research was to determine the current and future trends and issues facing technology and engineering education (TEE) in the United States (U.S.). The researchers used a three-round Modified-Delphi method to solicit information from technology and engineering education stakeholders across the U.S. In the first round, participants listed what they felt were current trends, future trends, current issues, and future issues facing TEE. The second round was designed to prioritize trends and issues. In the third round, participants were presented with one table for each current and future trend and issue and asked to identify if they felt each was essential or non-essential for technology and engineering leaders to address. Two hundred sixty-eight participants responded in the third round, and the resulting trends and issues were categorized into eight themes: 1) teacher shortage; 2) secondary and university TEE programs; 3 ) funding programs and teachers; 4) curriculum; 5) technology and engineering education identity and relevance; 6) collaborative efforts; 7) teacher certification and development; and 8) student-centered foci.
\end{abstract}

Keywords: Technology and engineering education, Delphi technique, trends, strategic planning

Education is continually changing because of research, practice, societal trends, and issues. For example, $64 \%$ of the public in the U.S. feel there is too much emphasis on standardized testing, and "less than half of adults (42\%) say performance on standardized tests is a highly important indicator of school quality" (Phi Delta Kappan, 2017, p. K5). Public opinion may be a factor in shaping the future use of standardized testing. How do such broad societal and educational trends and issues impact TEE? These points, among others, are opportunities for the TEE profession to reassess, then formulate a strategic plan to address such concerns. In this study, TEE stakeholders identified current and future trends and issues specific to TEE in the U.S.

Moye, J. J., Reed, P. A., Wu-Rorrer, R., \& Lecorchick, D. (2020). Current and future trends and issues facing technology and engineering education in the United States. Journal of Technology Education, 32(1), 35-49. https://doi.org/10.21061/jte.v32i1.a.3 


\section{Literature on Trends and Issues in Technology Education}

Research to discern trends and issues in technology education has a welldocumented history. Schmitt and Pelley (1966) conducted a comprehensive survey of industrial arts programs, teachers, students, and curriculum in the U.S. Their report provided a national snapshot of the profession and set the tone for the paradigm shift from industrial practice to technology. Conducting a thorough review of the profession in the U.S., Sanders (2001) used some of Schmitt and Pelley's (1966) questions, items from the Standards for Industrial Arts Programs study (Dugger, et al., 1980) as well as questions from surveys conducted by the periodical, School Shop/Tech Directions, in 1986, 1989, 1990, and 1991.

Sanders (2001) concluded that the profession was undergoing a significant transition but still had firm roots in its industrial past.

Periodic reviews and synthesis of literature from 1966 to 1994 have also outlined trends and issues in TEE. Dissertations, journal articles, and other publications were reviewed and classified to provide the profession with a clear picture of where things stood and opportunities (Dyrenfurth \& Householder, 1979; Householder \& Suess, 1969; McCrory, 1987; Streichler, 1966; Zuga, 1994). Similar reviews of graduate studies have also been valuable in tracking trends and issues (Foster, 1992; Jelden, 1981; Reed, 2001; Reed \& Sontos, 2006; Volk, 1997). Reed and LaPorte (2015) discerned the profession's long-term and emerging trends by analyzing the special interest sessions of the conferences of what is now known as the International Technology and Engineering Educators Association (ITEEA) from 1978-2014. These studies consistently showed that the profession has focused on curriculum (e.g., content, content development) and professional development activities, such as teacher certification.

Between 2001 and 2015, several studies were conducted on the status of technology (and engineering) education in the U.S. (Dugger, 2007; Meade \& Dugger, 2004; Moye, et al., 2015; Newberry, 2001). Numerous studies were conducted between 1989 and 2015 on the supply of, and demand for, technology and engineering teachers in the U.S. (Akmal, et al., 2002; Daugherty, 1998; Hoepfl, 2001; Moye, 2009; Moye, 2016; Ndahi \& Ritz, 2003; Ritz, 1999; Weston, 1997; Wright \& Custer; 1998; Wright \& Devier, 1989); these studies documented a downward trend in the number of technology teachers.

Using a modified Delphi technique, Wicklein took a different approach to identify critical problems and issues facing technology education in the U.S. $(1993,2005)$. The participants in Wicklein's 1993 study consisted of a purposefully selected panel of experts, whereas his 2005 study used a stratified sample of teachers, teacher educators, and administrators. In his 1993 study, Wicklein found the following three overarching themes: (a) curriculum needs, (b) knowledge base concerns, and (c) interdisciplinary approaches to teaching. The 2005 study produced four themes: (a) teacher recruitment concerns, (b) inadequate understanding of technology education, (c) curriculum design and development, and (d) procuring adequate funding for technology programs. 
In 1996 Wicklein and Hill conducted a study to "identify a concise list of constraints representative of the issues and problems facing Technology Education" (p. 31). Their results revealed eight factors similar to the data found in Wicklein's 1993 and 2005 studies. These were: (a) funding, (b) academic content, (c) program vitality, (d) leadership, (e) research base, (f) teacher supply, (g) identity, and (h) integration. Katsioloudis and Moye (2012) studied issues and problems facing TEE in the Commonwealth of Virginia, uncovering five areas of concern: (a) administrators'/counselors' lack of understanding, (b) secondary student enrollment, (c) better marketing needs, (d) TEE teacher program closures, and (e) lack of research showing benefits of TEE. Reed (2006) conducted a review of literature that spanned a 12-year period between Wicklein's 1993 to 2005 studies and included published literature and graduate research. The findings indicated that the top five problems and issues identified by Wicklein were being addressed by the profession but at varying degrees. Clearly, with the passage of 15 years since Wicklein's 2005 study, there is a need to update national research on TEE's trends and issues in the United States.

\section{Purpose}

The purpose of this research was to determine the current and future trends and issues facing TEE in the U.S. During the 2019-2020 academic year, the researchers used Wicklein's study, Identifying Critical Issues and Problems in Technology Education Using a Modified-Delphi Technique (1993), to guide this study. Rather than studying problems and issues, the researchers focused on trends and issues.

The researchers sought answers to the following four questions:

1. What trends currently impact the TEE profession?

2. What issues currently impact the TEE profession?

3. What trends will most likely impact the TEE profession in the next three to five years?

4. What issues will most likely impact the TEE profession in the next three to five years?

A trend was defined for research subjects as a general direction in which TEE is developing or changing. An issue was defined as something of "importance relating to at least two points of view that are debatable or in dispute with technology [and engineering] education" (Wicklein, 1993, p. 56). Current was defined as of the present time. Lastly, the future was defined as a projected period of time between now and the next three to five years.

\section{Methodology}

The researchers used a modified Delphi method to solicit information from TEE stakeholders in the U.S. A stakeholder was considered someone with a vested interest in TEE, such as TEE teachers, teacher educators, and administrators. Hsu and Sandford (2007) identified that "the Delphi technique is 
a widely used and accepted method for gathering data from respondents within their domain of expertise" (p. 1). The Delphi technique was selected because stakeholders were geographically dispersed, it is a cost-effective method that can be conducted electronically, and it provides sufficient time for participants to reflect and comment. Additionally, Delphi studies typically range from three to five rounds, depending on the level of consensus the researchers seek (Hsu \& Sandford, 2007).

\section{Participants}

While Hsu and Sandford (2007) noted that there is no exact standard for selecting Delphi participants, they did recommend that participants should be selected from among the stakeholders within the area being researched. Following Wicklein's (1993) methodology, the researchers of this study requested that ITEEA members nominate experts in the field of TEE. After two rounds of soliciting potential experts, 100 names were received. Of those, only 26 agreed to participate, and they did not sufficiently represent diverse demographics and all four ITEEA geographic regions. To compensate for these limitations, the researchers invited additional stakeholders, as Wicklein had done in his 2005 study, where his research goal was to "ascertain the perspectives of classroom teachers, university professors, and supervisors of technology education" (p. 6).

Requests for participants were sent via ITEEA communications, including the IdeaGarden listserv and STEM Connections newsletter. Once all ITEEA regions were well represented, the Delphi study began. The number of participants varied during the three rounds. In round one, 320 stakeholders participated, with $33 \%$ identifying as $9-12^{\text {th }}$ grade TEE teachers (see Table 1 ). In round one, $68.5 \%$ of participants identified as male and $31 \%$ as female. Two hundred eighty-three (88.4\%) of the respondents identified as White/Caucasian; eight (2.5\%) as Hispanic/Latino, seven (2.2\%) as Black/African American, six $(1.9 \%)$ as Asian/Asian American, and one (.3\%) as American Indian/Alaska Native. Four (1.3\%) reported mixed races, and 11 (3.4\%) participants preferred not to identify their race.

The researchers asked participants to report in which state they were employed. Three hundred-fifteen responded with 192 (60.9\%) responses from ITEEA Region 1 (Eastern), 37 (11.7\%) from Region 2 (East Central), 53 (16.8\%) from Region 3 (West Central), and 33 (10.5\%) in Region 4 (Western). Middle school and high school TEE teachers and TEE teacher educators represented $70 \%$ of respondents. All percentages were rounded and, although the numbers indicate a cross-section of regional stakeholders, they may not be representative of ITEEA members in those regions or of TEE stakeholders in those regions. 


\section{Procedure}

In the first round, participants were provided definitions for current, future, trends, and issues and asked to list what they felt were current trends, future trends, current issues, and future issues facing TEE in the U.S. The researchers organized the responses from round one into the four trends and issues categories (i.e., current and future trends, current and future issues) to be used in round two (Hsu \& Sanford, 2007).

Table 1

Stakeholder Participation by Role

\begin{tabular}{lcccc}
\hline \multicolumn{1}{c}{ Position } & \multicolumn{2}{c}{ Round I } & \multicolumn{2}{c}{ Round III } \\
\cline { 2 - 5 } & $\mathbf{n}$ & $\mathbf{\%}$ & $\mathbf{n}$ & $\mathbf{\%}$ \\
\hline TEE Participants & & & & \\
9-12 Teacher & 106 & 33 & 91 & 34 \\
Teacher Educator & 66 & 21 & 59 & 22 \\
6-8 Teacher & 50 & 16 & 52 & 19 \\
State Administrator & 15 & 5 & 8 & 3 \\
Local Administrator & 12 & 4 & 12 & 4 \\
Teacher Candidate & 10 & 3 & 9 & 3 \\
PreK-5 Teacher & 10 & 3 & 7 & 3 \\
Non-TEE Participants & & & & \\
Business Leader & 6 & 2 & 5 & 2 \\
9-12 Teacher & 7 & 0.0 & 1 & 0.0 \\
6-8 Teacher & 2 & 0.0 & 2 & 0.0 \\
PK-5 Teacher & 4 & 0.0 & 2 & 0.0 \\
Administrator & 9 & 0.0 & 12 & 0.0 \\
Others & 23 & 0.1 & 8 & 0.0 \\
\hline TOTAL & $\mathbf{3 2 0}$ & $\mathbf{1 0 0}$ & $\mathbf{2 6 8}$ & $\mathbf{1 0 0}$ \\
\hline
\end{tabular}

The second round was designed to prioritize each trend and issue in each of the four trends and issues categories. The researchers emailed participants a cover letter and link to four tables showing categorized trends and issues. Participants were asked to indicate how much they agree or disagree with each trend or issue as being important for technology and engineering leaders to address. Participants indicated their agreement on a five-point scale ranging 
from 1 to $5(1=$ strongly disagree to $5=$ strongly agree $)$. After round two, the mean of each trend and issue was calculated, then ranked from highest to lowest.

In the third round, participants were asked to identify if they felt each trend and each issue were essential or non-essential for technology and engineering leaders to address. The means of each trend and each issue were tabulated and ranked. Based on that data, the researchers created four tables. Each table contained columns comparing the mean of each key descriptor found in rounds two and three. Using the resulting data, the researchers categorized the trends and issues into eight different themes.

\section{Results}

In the initial round, 320 participants submitted a total of 3,612 trends and issues. Of those responses, the researchers classified 801 as current issues, 565 as future issues, 1,402 as current trends, and 844 as future trends. The researchers consolidated similar items and placed the responses into the four categories, resulting in 20 current trends, 21 future trends, 17 current issues, and 20 future issues. These trends and issues became the inputs for rounds two and three.

The purpose of round two was to determine what participants felt were the most important current and future trends and issues. Despite email reminders, there were only 176 participants in round two, which represented $55 \%$ of the respondents in round one. This may have been a result of survey fatigue.

Anticipating further declines in participation, the researchers decided to limit the study to three rounds (Hsu \& Sandford, 2007). This decision was also based on the strong means from round two, which indicated high levels of agreement among participants. On a five-point scale ranging from 1 (strongly disagree) to 5 (strongly agree), the 20 current trends had means ranging 3.52-4.66. The 21 future trends had means ranging 3.62-4.62. The 17 current issues had means ranging 3.50-4.45. The 20 future issues had means ranging 3.68-4.59.

In the final round of this study, participants were asked if they considered each of the key descriptors to be essential or non-essential for TEE leaders to address in future strategic planning. Two hundred sixty-eight stakeholders responded. The number of judgments as essential and non-essential were calculated, resulting in percentages used to rank inputs from most to least essential. The resulting 78 trends and issues were categorized by the researchers into themes, similarly to previous studies (Katsioloudis \& Moye, 2012; Wicklein 1993; Wicklein, 2005; Wicklein \& Hill, 1996). Current and future trends and issues are shown in Table 2, categorized by eight themes. The left column identifies each individual theme. The row following each theme identifies specific trends and issues associated with that theme. The number preceding each trend and issue is the round three ranking. 
Table 2

Trends and Issues Facing Technology and Engineering EducationCategorized into Themes

\begin{tabular}{|c|c|c|c|c|}
\hline Theme & Current Trend & Future Trend & Current Issue & Future Issue \\
\hline $\begin{array}{l}\text { Critical } \\
\text { Teacher } \\
\text { Shortage }\end{array}$ & $\# 1$ Teacher shortage & $\# 1$ Teacher shortage & $\begin{array}{l}\text { \#1 Low recruitment } \\
\text { of teachers }\end{array}$ & $\# 1$ Teacher shortage \\
\hline \multirow[t]{8}{*}{ Curriculum } & $\begin{array}{l}\text { \#2 Hands-on projects: } \\
\text { Students doing more }\end{array}$ & $\begin{array}{l}\# 3 \text { Project-based } \\
\text { learning / hands-on } \\
\text { projects: Need more, } \\
\text { promote importance }\end{array}$ & $\begin{array}{l}\text { \#2 Project-based } \\
\text { learning / hands-on } \\
\text { projects: Need more, } \\
\text { promote importance }\end{array}$ & $\begin{array}{l}\text { \#7 Interdisciplinary / } \\
\text { STEM approach: } \\
\text { TEE role }\end{array}$ \\
\hline & $\begin{array}{l}\text { \#6 College } \\
\text { preparation: TEE role }\end{array}$ & $\begin{array}{l}\text { \#8 TEE course / } \\
\text { curricular content: } \\
\text { What should be } \\
\text { taught }\end{array}$ & $\begin{array}{l}\text { \#7 STEM education: } \\
\text { TEE role }\end{array}$ & $\begin{array}{l}\text { \#9 TEE course / } \\
\text { curricular content: } \\
\text { What should be } \\
\text { taught }\end{array}$ \\
\hline & $\begin{array}{l}\text { \#7 TEE course / } \\
\text { curricular content: } \\
\text { What should be taught }\end{array}$ & $\begin{array}{l}\text { \#9 Integrative } \\
\text { STEM Education: } \\
\text { TEE role }\end{array}$ & $\begin{array}{l}\# 10 \text { TEE course / } \\
\text { curricular content: } \\
\text { What should be } \\
\text { taught }\end{array}$ & $\begin{array}{l}\text { \#11 Occupation } \\
\text { preparation: TEE } \\
\text { role }\end{array}$ \\
\hline & $\begin{array}{l}\text { \#9 Integrative STEM } \\
\text { Education: TEE role }\end{array}$ & $\begin{array}{l}\text { \#14 TEE standards: } \\
\text { Need to be updated }\end{array}$ & $\begin{array}{l}\text { \#15 TEE standards: } \\
\text { Need to be updated }\end{array}$ & $\begin{array}{l}\text { \#12 TEE standards: } \\
\text { Need to be updated }\end{array}$ \\
\hline & $\begin{array}{l}\# 12 \text { Computer } \\
\text { Science Education: } \\
\text { TEE teaching more }\end{array}$ & $\begin{array}{l}\text { \#15 Occupation } \\
\text { prep: TEE role }\end{array}$ & $\begin{array}{l}\text { \#17 Industrial arts to } \\
\text { TEE: Slow change }\end{array}$ & $\begin{array}{l}\# 14 \text { College } \\
\text { preparation: TEE } \\
\text { role }\end{array}$ \\
\hline & $\begin{array}{l}\text { \#14 Occupation } \\
\text { preparation: TEE role }\end{array}$ & $\begin{array}{l}\text { \#16 College prep: } \\
\text { TEE role }\end{array}$ & & $\begin{array}{l}\text { \#15 TEE teaching } \\
\text { methodology: Need } \\
\text { focus }\end{array}$ \\
\hline & $\begin{array}{l}\text { \#17 Elementary TEE: } \\
\text { Need focus }\end{array}$ & & & \\
\hline & $\begin{array}{l}\text { \#19 Robotics } \\
\text { Instruction: Becoming } \\
\text { popular }\end{array}$ & & & \\
\hline $\begin{array}{l}\text { Secondary \& } \\
\text { University }\end{array}$ & $\begin{array}{l}\text { \#5 TEE funding: Lack } \\
\text { of }\end{array}$ & $\begin{array}{l}\text { \#7 TEE funding: } \\
\text { Lack of }\end{array}$ & $\begin{array}{l}\text { \#8 TEE funding: } \\
\text { Lack of }\end{array}$ & $\begin{array}{l}\text { \#6 TEE funding: } \\
\text { Lack of }\end{array}$ \\
\hline $\begin{array}{l}\text { Program } \\
\text { Closures }\end{array}$ & & $\begin{array}{l}\text { \#13 TEE teacher } \\
\text { compensation: Low } \\
\text { compared to } \\
\text { industry }\end{array}$ & $\begin{array}{l}\text { \#14 Teacher } \\
\text { compensation: Low } \\
\text { compared to } \\
\text { industry }\end{array}$ & $\begin{array}{l}\text { \#13 Teacher } \\
\text { compensation: Low } \\
\text { compared to } \\
\text { industry }\end{array}$ \\
\hline \multirow{2}{*}{$\begin{array}{l}\text { Funding: } \\
\text { Programs \& } \\
\text { Teachers }\end{array}$} & \#5 TEE funding: Lack & \#7 TEE funding: & \#8 TEE funding: & \#6 TEE funding: \\
\hline & & $\begin{array}{l}\text { \#13 TEE teacher } \\
\text { compensation: Low } \\
\text { compared to } \\
\text { industry }\end{array}$ & $\begin{array}{l}\text { \#14 Teacher } \\
\text { compensation: Low } \\
\text { compared to } \\
\text { industry }\end{array}$ & $\begin{array}{l}\text { \#13 Teacher } \\
\text { compensation: Low } \\
\text { compared to } \\
\text { industry }\end{array}$ \\
\hline
\end{tabular}


Table 2, continued from Page 41

\begin{tabular}{|c|c|c|c|c|}
\hline \multirow[t]{2}{*}{$\begin{array}{l}\text { TEE Identity } \\
\text { \& Relevance }\end{array}$} & $\begin{array}{l}\text { \#4 Administrators \& } \\
\text { counselors: } \\
\text { Misunderstand / lack } \\
\text { of TEE support }\end{array}$ & $\begin{array}{l}\text { \#11 Poor public } \\
\text { relations for TEE }\end{array}$ & $\begin{array}{l}\text { \#6 Identity: What is } \\
\text { TEE }\end{array}$ & \multirow[t]{2}{*}{$\begin{array}{l}\# 4 \text { TEE validity / } \\
\text { relevance: Lack of } \\
\text { public understanding }\end{array}$} \\
\hline & $\begin{array}{l}\text { \#11 TEE marketing / } \\
\text { public relations: } \\
\text { Inadequate }\end{array}$ & & $\begin{array}{l}\text { \#11 Stigma: TEE } \\
\text { being an elective } \\
\text { course }\end{array}$ & \\
\hline \multirow[t]{2}{*}{$\begin{array}{l}\text { Collaborative } \\
\text { Efforts }\end{array}$} & \multirow[t]{2}{*}{$\begin{array}{l}\text { \#13 TEE taught by } \\
\text { other teachers: e.g., } \\
\text { science, librarians }\end{array}$} & $\begin{array}{l}\text { \#6 Business, } \\
\text { industry, \& political } \\
\text { support for TEE: } \\
\text { Lack of }\end{array}$ & $\begin{array}{l}\text { \#5 Collaboration: } \\
\text { Community / } \\
\text { Business / Industry }\end{array}$ & $\begin{array}{l}\text { \#5 Collaboration: } \\
\text { Community / } \\
\text { Business / Industry }\end{array}$ \\
\hline & & $\begin{array}{l}\text { \#17 TEE taught by } \\
\text { other teachers, e.g., } \\
\text { science, librarians }\end{array}$ & $\begin{array}{l}\text { \#13 Collaborate: } \\
\text { Teachers of other } \\
\text { content areas }\end{array}$ & $\begin{array}{l}\text { \#16 Collaborate: } \\
\text { Teachers of other } \\
\text { content areas }\end{array}$ \\
\hline \multirow[t]{3}{*}{$\begin{array}{l}\text { Teacher } \\
\text { Certification / } \\
\text { Development }\end{array}$} & $\begin{array}{l}\text { \#8 TEE teacher } \\
\text { preparation: } \\
\text { Inadequate / } \\
\text { inappropriate }\end{array}$ & $\begin{array}{l}\text { \#10 TEE teacher } \\
\text { professional } \\
\text { development: Needs } \\
\text { improved }\end{array}$ & $\begin{array}{l}\text { \#9 Teacher } \\
\text { professional } \\
\text { development: Needs } \\
\text { improved }\end{array}$ & $\begin{array}{l}\text { \#8 TEE teacher } \\
\text { preparation: } \\
\text { Inadequate / } \\
\text { inappropriate }\end{array}$ \\
\hline & \multirow[t]{2}{*}{$\begin{array}{l}\text { \#18 Inadequate / } \\
\text { ineffective TEE } \\
\text { leadership }\end{array}$} & $\begin{array}{l}\text { \#12 TEE teacher } \\
\text { preparation: } \\
\text { Inadequate / } \\
\text { inappropriate }\end{array}$ & $\begin{array}{l}\# 12 \text { TEE teacher } \\
\text { preparation: } \\
\text { Inadequate / } \\
\text { Inappropriate }\end{array}$ & $\begin{array}{l}\text { \#10 TEE teacher } \\
\text { professional } \\
\text { development: } \\
\text { Leadership role }\end{array}$ \\
\hline & & $\begin{array}{l}\text { \#18 TEE leadership } \\
\text { \& leadership } \\
\text { training: Inadequate }\end{array}$ & & $\begin{array}{l}\# 18 \text { TEE teacher } \\
\text { certification: } \\
\text { Alternate vs. } \\
\text { traditional } \\
\end{array}$ \\
\hline \multirow[t]{3}{*}{$\begin{array}{l}\text { Student- } \\
\text { Centered Foci }\end{array}$} & $\begin{array}{l}\# 10 \text { High school } \\
\text { graduation } \\
\text { requirements: } \\
\text { Restrictions on TEE }\end{array}$ & $\begin{array}{l}\text { \#20 TEE Student } \\
\text { Diversity / Equity / } \\
\text { Inclusion: Improve }\end{array}$ & $\begin{array}{l}\text { \#16 TEE Student } \\
\text { Diversity / Equity / } \\
\text { Inclusion: Improve }\end{array}$ & $\begin{array}{l}\text { \#19 TEE Student } \\
\text { Diversity / Equity / } \\
\text { Inclusion: Improve }\end{array}$ \\
\hline & $\begin{array}{l}\text { \#16 TEE Student } \\
\text { Diversity / Equity / } \\
\text { Inclusion: Improve }\end{array}$ & $\begin{array}{l}\text { \#21 Student } \\
\text { development of } \\
\text { critical thinking \& } \\
\text { problem solving } \\
\text { skills: TEE role }\end{array}$ & & \\
\hline & $\begin{array}{l}\text { \#20 Standardized } \\
\text { student testing: } \\
\text { Becoming focus }\end{array}$ & & & \\
\hline
\end{tabular}

\section{Discussion}

The purpose of this research was to determine the current and future trends and issues facing the TEE profession in the U.S. Using Wicklein's 1993 and 2005 studies as guides, this study addressed four research questions: What trends currently impact the TEE profession? What issues currently impact the TEE profession? What trends will most likely impact the TEE profession in the 
next three to five years? Lastly, what issues will most likely impact the technology and engineering profession in the next three to five years?

The critical shortage of technology and engineering teachers has been of concern for many years (Wicklein, 1993, 2005; Volk, 1997; Moye, 2009, 2016) and was identified in this study as the top priority for leaders to address. Why does this problem persist? The profession has not adequately addressed this problem. Perhaps leaders are looking at the wrong variables and using ineffective strategies. The proliferation of makerspaces in PK-12 schools, technical competitions, engineering design in Next Generation Science Standards (NGSS Lead States, 2013), and other initiatives are a clear affirmation that TEE is valued (Reed, 2018). The Phi Delta Kappan (2017) survey of the public's attitudes toward public schools showed that $82 \%$ of respondents view TEE as an important indicator of school quality. Clearly, the profession must rectify the teacher shortage in light of the valued content the field offers.

Directly related to the teacher shortage is the closure of many secondary school and university programs. Wicklein (2005) stressed,

The most obvious conclusion from this research is the concern and crisis over the insufficient quantities of qualified new technology educators entering the instructional rank.... the dilemma over recruitment and preparation of new technology teachers coming from university programs dwarfs all of the other concerns. (p. 8)

Both secondary school and university programs require a large physical footprint, are costly to maintain, and will close if there are too few students or teachers to populate those programs. However, the profession has shown growth in elementary school TEE, which tends to take an integrative approach (Reed \& LaPorte, 2015). Perhaps secondary school and college/university programs should re-conceive the costly, large laboratory approach as there are many proven alternative approaches for TEE (Helgeson \& Schwaller, 2003; Petrina, 2007).

Funding for programs and teachers is complex in the U.S. since education is largely a state and local endeavor. However, the recent passage of Perkins V, the Strengthening Career and Technical Education for the $21^{\text {st }}$ Century Act (2018), continues federal funding for states that classify TEE under career and technical education (CTE). To address funding concerns at all levels, teacher educators and administrators may want to increase pre-service and in-service education on funding and grant requests. Having robust information on federal, state, local, and private funding may alleviate concerns and strengthen program funding.

Curriculum, more so than funding, is a state and local endeavor in the U.S. However, the TEE profession, through the work of ITEEA, has received federal grant funding over the past thirty years to develop content standards (ITEEA, 
2000, 2020). Standards for Technological and Engineering Literacy: The Role of Technology and Engineering in STEM Education (STEL) is structured so it can be adapted to state and local educational models (ITEEA, 2020, pp. 16-17). Like funding, a continuous professional development effort should be made to help stakeholders understand STEL, other standards (e.g., NGSS), and contemporary curricular topics (i.e., makerspaces, robotics, student organizations).

The identity and relevance of TEE was a theme with diverse trends and issues. The public, administrators, and counselors seem to be groups that, according to participants in this study, need to be better informed. ITEEA's $(2000,2020)$ standards projects have provided a unified vision and content. Still, the National Academies (Katehi \& Pearson, 2009) and the National Assessment Governing Board (National Assessment for Educational Progress, n.d.) suggested there are problems and issues related to identity and relevance. The profession needs to take a systemic approach to address identity and relevance.

Participants' comments concerning collaboration were mixed. Many asserted that TEE is collaborative by nature, while others felt threatened that groups like science teachers and library media specialists were becoming more active in delivering traditional TEE learning activities and content. Collaboration should be embraced because it may result in more students and stakeholders becoming involved in TEE programs and courses. Some states have developed plans that promote the integration of science, technology, engineering, and mathematics (STEM) education (Indiana Department of Education, 2018; Virginia STEM Education Commission, 2020). The profession must do a better job of defining and promoting collaboration within the field and more broadly through initiatives such as STEM ${ }^{4}$ : The Power of Collaboration for Change (Advance CTE, et al., 2018).

Participants identified that TEE teacher preparation programs are inadequate and need to be improved. This theme is interrelated to others, so there may be symbiotic solutions. For example, the Praxis Technology Education assessment (Educational Testing Service, 2020) is based on outdated curriculum organizers, which may contribute to identity problems and curricular issues. If licensing guidelines require teacher preparation programs to use this assessment, then the program is inadequate and needs improvement, as do the assessment and licensure guidelines.

The theme labeled student-centered foci was broad, including topics such as diversity, equity, TEE practices, and inclusion, among others. Like many trends and issues, communicating a clear vision of TEE based on research, practice through professional development and outreach can address student-centered foci concerns. Many of these student-centered foci trends and issues apply across education, not just TEE, and therefore addressing them does not fall solely on the TEE profession. 
The findings of this study reflect the findings from previous research (Wicklein, 1993, 2005; Wicklein \& Hill, 1996; Katsioloudis \& Moye, 2012). Technology and engineering educators at all levels need to work on these trends and issues, but a first step is understanding what work has already been done. For example, Reed (2006) reviewed the professional literature between Wicklein's 1993 and 2005 studies and found that all identified problems and issues were being addressed at varying levels. Similar research should be conducted to determine what has and has not been done more recently to address these persistent trends and issues. Such research may indicate that some trends and issues are being addressed but the ways they are being addressed may need to be communicated more effectively. Additionally, since some trends and issues have consistently been identified in the literature, perhaps TEE needs to come to terms that some are actually foundational benchmarks of the discipline. For example, the profession's ongoing fascination with curriculum may be a result of educational progress or technological advances. The profession may need to embrace these persistent trends and issues as standard measures to shape TEE through strategic planning.

\section{References}

Advance CTE, Association of State Supervisors of Mathematics (ASSM), Council of State Science Supervisors (CSSS), \& International Technology and Engineering Educators Association (ITEEA). (2018). STEM ${ }^{4}$ : The Power of Collaboration for Change. https://www.iteea.org/File.aspx?id=137271\&v=cb3f06a2

Akmal, T., Oaks, M. M., \& Barker, R. (2002). The status of technology education: A national report on the state of the profession. Journal of Industrial Teacher Education, 39(4). https://scholar.lib.vt.edu/ejournals/JITE/v39n4/akmal.html

Daugherty, M. (1998). A recruitment crisis: Strategies for affecting change. The Technology Teacher, 57(7), 21-26.

Dugger, W. E. (2007). The status of technology education in the United States: A triennial report of the findings from the states. The Technology Teacher, 67(1), 14-21.

Dugger, W. E., Bame, E. A., Pinder, C. A., \& Miller, C. D. (1980). Standards for industrial arts education programs: A project report. Journal of Epsilon Pi Tau, 6(2), 13-22.

Dyrenfurth, M. J. \& Householder, D. L. (1979). Industrial Arts Education: A review and synthesis of the research, 1968-1979 (ED185239). ERIC. http://files.eric.ed.gov/fulltext/ED185239.pdf

Educational Testing Service. (2020). Praxis: for test takers: technology education. https://www.ets.org/praxis/prepare/materials/5051 
Foster, W. T. (Editor). (1992). Electronic supplement to the Journal of Technology Education: A partial bibliography of recent graduate research in technology education and related fields. https://scholar.lib.vt.edu/ejournals/JTE/supplements/FosterBibliography.ht $\mathrm{ml}$

Helgeson, K. \& Schwaller, A. (Eds.). (2003). Selecting instructional strategies for technology education. 52nd Council on Technology and Engineering Teacher Education Yearbook. http://hdl.handle.net/10919/19152

Hoepfl, M. (2001). Alternative routes to certification of technology education teachers. Journal of Technology Studies, 27(2), 35-44. https://doi.org/10.21061/jots.v27i2.a.2

Householder, D., \& Suess, A. (1969). Review and synthesis of research in industrial arts education (2nd Ed.) (ED034898). ERIC. https://files.eric.ed.gov/fulltext/ED034898.pdf

Hsu, C. C., \& Sandford, B. A. (2007). The Delphi technique: Making sense of consensus. Practical Assessment, Research, and Evaluation, 12(10), 1-8. https://doi.org/10.7275/pdz9-th90

Indiana Department of Education. (2018). Indiana STEM: STEM six year strategic plan - An integrated K-12 STEM approach for Indiana. https://www.doe.in.gov/sites/default/files/wf-stem/20181108154535030.pdf

International Technology and Engineering Educators Association. (2000). Standards for technological literacy: Content for the study of technology. https://www.iteea.org/Activities/2142/Technological_Literacy_Standards.as px

International Technology and Engineering Educators Association. (2020). Standards for technological and engineering literacy: The role of technology and engineering in STEM education. https://www.iteea.org/STEL.aspx

Jelden, D. L. (Ed.). (1981). Summaries of studies in industrial arts, trade and industrial, and technical education. Greeley, CO: University of Northern Colorado.

Katsioloudis, P. \& Moye, J. J. (2012). Future critical issues and problems facing technology and engineering education in the commonwealth of Virginia. Journal of Technology Education, 23(2), 6-24. https://doi.org/10.21061/jte.v23i2.a.1

Katehi, L., Pearson, G., \& Feder, M. (Eds.). (2009). Engineering in K-12 education: Understanding the status and improving the prospects. National Academies Press. https://doi.org/10.17226/12635

McCrory, D. L. (1987). Technology education: industrial arts in transition. A review and synthesis of the research (4th Ed.) (ED290935). ERIC. https://files.eric.ed.gov/fulltext/ED290935.pdf

Meade, S. D., \& Dugger, W. E., Jr. (2004). Reporting on the status of technology education in the U.S. The Technology Teacher, 64(2), 29-33. 
Moye, J. J. (2009). Technology education teacher supply and demand - A critical situation. The Technology Teacher 69(2), 30-36.

Moye, J. J. (2016). The supply and demand of technology and engineering teachers in the U.S.: Who knows? Technology and Engineering Teacher, 76(4). 32-37.

Moye, J. J., Jones, V. R., \& Dugger, W. E. Jr. (2015). Status of technology and engineering education in the United States: A fifth report of the findings from the states (2014-2015). Technology and Engineering Teacher, 74(7), 30-36.

National Assessment for Educational Progress. (NAEP). (n.d.). Technology and engineering literacy. https://nces.ed.gov/nationsreportcard/tel/

Ndahi, H. B., \& Ritz, J. M. (2003). Technology education teacher demand, 2002-2005. The Technology Teacher, 62(7), 27-31.

Newberry, P. B. (2001). Technology education in the U.S.: A status report. The Technology Teacher, 61(1), 8-12.

NGSS Lead States. (2013). Next generation science standards: For states, by states. Washington, DC: The National Academies Press.

Petrina, S. (2007). Advanced teaching methods for the technology classroom. Hershey, PA: Information Science Publishing. https://doi.org/10.4018/978-1-59904-337-1

Phi Delta Kappa International (PDK). (2017). Academic achievement isn't the only mission. Americans overwhelmingly support investments in career preparation, personal skills. $49^{\text {th }}$ PDK/Gallup Poll of Public's Attitudes Toward the Public Schools. Phi Delta Kappan, 99(1), K1-K31. https://doi.org/10.1177/0031721717728274

Reed, P. A. (Editor). (2001). Monograph \#17: The technology education graduate research database: 1892-2000. Reston, VA: Council on Technology Teacher Education. http://ctete.org/wpcontent/uploads/2016/03/Mono17GradResearchDatabase.pdf

Reed, P. A. (2006). What do we value? Research on technology education problems, issues, and standards in the United States. Paper presented at the 4th Biennial Technology Education Research Conference, Surfer's Paradise, Australia. https://www.researchgate.net/publication/306211254_What_Do_We_Value _Research_on_Technology_Education_Problems_Issues_and_Standards_in the United_States

Reed, P. A. (2018). Reflections on STEM, standards, and disciplinary focus. Technology and Engineering Teacher, 77(7), 16-20.

Reed, P. A. \& LaPorte, J. E. (2015). A content analysis of AIAA/ITEA/ITEEA conference special interest sessions: 1978-2014. Journal of Technology Education, 26(3), 38-73. https://doi.org/10.21061/jte.v26i3.a.2 
Reed, P. A. \& Sontos, D. (2006). A United States perspective: 112 years of graduate research in technology education. Paper presented at the 16th Pupils Attitudes towards Technology (PATT-16) Conference, Baltimore, MD. https: $/ /$ www.iteea.org $/$ File.aspx?id $=86523 \& v=379$ cca 79

Ritz, J. M. (1999). Addressing the shortage of technology education teaching professionals: Everyone's business. The Technology Teacher, 59(1), 8-12.

Sanders, M. E. (2001). New paradigm or old wine? The status of technology education practice in the United States. Journal of Technology Education, 12(2), 35-55. https://doi.org/10.21061/jte.v12i2.a.3

Schmitt, M. L. \& Pelley, A. L. (1966). Industrial arts education: A survey of programs, teachers, students, and curriculum. U. S. Department of Health, Education, and Welfare. OE 33038, Circular No. 791. Washington, DC: U.S. Government Printing Office.

Streichler, J. (1966). Review and synthesis of research in industrial arts education. (ED011564). ERIC. https://files.eric.ed.gov/fulltext/ED011564.pdf

Strengthening Career and Technical Education for the $21^{\text {st }}$ Century Act of 2018, Pub. L. No. 115-224, page 132, Stat. 1563 (2018). https://www.congress.gov/bill/115th-congress/house-bill/2353/

Virginia STEM Education Commission. (2020). Virginia STEM education commission final report.

https://www.governor.virginia.gov/media/governorvirginiagov/secretary-ofeducation/pdf/STEM-Plan-executive-summary.pdf

Volk, K. S. (1997). Going, going, gone? Recent trends in technology teacher education programs. Journal of Technology Education, 8(2), 66-70. https://doi.org/10.21061/jte.v8i2.a.5

Weston, S. (1997). Teacher shortage - Supply and demand. The Technology Teacher, 57(1), 6-9.

Wicklein, R. C. (1993). Identifying critical issues and problems in technology education using a modified-Delphi technique. Journal of Technology Education, 5(1), 54-71. https://doi.org/10.21061/jte.v5i1.a.5

Wicklein, R. C. (2005). Critical issues and problems in technology education. The Technology Teacher, 64(4), 6-9.

Wicklein, R. C., \& Hill, R. (1996). Navigating the straits with research or opinion? Setting the course for technology education. International Journal of Technology and Design Education, 6, 31-43. https://doi.org/10.1007/BF00571071

Wright, M., \& Custer, R. (1998). Why they want to teach: Factors influencing students to become technology education teachers. Journal of Technology Education, 10(1), 58-70. https://doi.org/10.21061/jte.v10i1.a.4 
Wright, M. D. \& Devier, D. H. (1989). An impending crisis: The supply and demand of Ohio industrial technology teachers 1988-1992. Paper presented at the annual convention of the American Vocational Association, Orlando, FL.

Zuga, K. (1994). Implementing technology education: A review and synthesis of the research literature (ED372305). ERIC.

https://files.eric.ed.gov/fulltext/ED372305.pdf

\section{About the Authors}

Johnny J. Moye (jmoye@iteea.org) is Senior Fellow at the International Technology and Engineering Educators Association in Reston, Virginia.

Philip A. Reed (preed@odu.edu) is Professor and Technology Education Program Leader at Old Dominion University in Norfolk, Virginia.

Ray Wu-Rorrer (wurorrerr@fccps.org) teaches at Mary Ellen Henderson Middle School in Fairfax, Virginia.

Douglas Lecorchick (lecorchickd@berea.edu) is Assistant Professor at Berea College in Berea, Kentucky. 